\title{
HANS KüNG, libertad conquistada
}

Cuando inicié este nuevo acercamiento a una personalidad que siempre admiré, se me deslizó en el título un artículo determinado. Iba a titular este approche Hans Küng o la libertad conquistada. Pero pronto me percaté de que el artículo determinado no se hallaba ni en el alemán "Erkümpfte Freiheit" ni en su traducción española "Libertad conquistada". Y debía existir alguna razón para ello. Se puede conquistar libertad, más o menos siempre, pero la libertad no se conquista nunca, porque ya desde la concepción y el nacimiento humano la libertad es limitada -nadie nos ha pedido permiso para venir a este mundo, así que "no somos libres para lo esencial"-. Y con Sartre, a quien Hans Küng aplaude en alguna ocasión y denigra en otras, podemos decir que "la libertad es un destierro y estoy condenado a ser libre”, o con Ortega y Gasset, aunque Hans Küng no haga aprecio de él, diremos que "somos libres a la fuerza". Tiene, pues, razón cuando a sus Memorias les coloca el título de Libertad conquistada, porque la libertad es siempre una conquista y parece que él la ha conquistado. Sus palabras, casi finales, de esta fascinante historia personal me suenan a algo conocido por vivido, me suenan a experiencia por vivencia, me suenan a realidad bien asumida:

"De hecho, cuando miro hacia atrás a punto de cumplir mis setenta y cinco años de vida, ¿cómo no sentir una gratitud infinita? ¿Gratitud por haber conservado la libertad que, por felices circunstancias, digamos que me pusieron en la cuna? ¿Porque esa libertad civil se haya acrisolado como libertad de conciencia? ¿Porque se me haya permitido vivirla como libertad de cristiano? ¿Porque se haya preservado como libertad en la Iglesia y en la teología? Con toda la modestia que aprendí en mi niñez: en medio de la confusión y el extravío de los tiempos yo he podido afirmarme como un hombre, un cristiano y un teólogo libre. Libertad conquistada y al mismo tiempo regalada. Se entiende así que no pueda nunca cantar el "Alaba, alma mía, al Señor" sin emoción, sobre todo cuando se llega a las palabras "que te lleva segura en alas de águi- 
la, que te mantiene como a ti te conviene. ¿No lo comprobaste tú también?". (HANS KÜNG, Libertad conquistada. Memorias. Editorial Trotta S.A. Madrid, 2003, p. 595).

Sí, yo también lo he comprobado, pero desde otra perspectiva distinta, que ha conquistado esa porción de libertad con hechos consumados, que me han dado en su vivencia la razón de cuanto había urdido en el pensamiento. Lo mismo, pero de otra manera, esa otra forma que apenas admite Hans Küng para los demás y que le obliga a dejarlos al margen y en el camino como al publicano, cuando pasaron los sacerdotes y lo abandonaron a su suerte en espera del samaritano. A quienes abandonaron para conquistar libertad se les abandona a su suerte -"se casaron", dice con cierto desprecio, con cierta ironía o ¿con cierta envidia?-.

Libertad conquistada es un canto al yo de quien la escribe y a un Atlas que carga sobre sus hombros los problemas de la Iglesia y les busca solución, apelando a todos los resortes disponibles para que su verdad sea la que prevalezca o predomine, descalificando a cuantos se interpongan en su camino y no comulguen con su manera de ver la realidad eclesial y se diría, su visión teológica de la misma. Existe en sus Memorias, tal vez en su recuerdo o quizás en su subconsciente, una obsesión, una especie de psicosis, de Ottaviani, como encarnación de todos los poderes curiales y de una Iglesia que busca exclusivamente, según él, el poder y los privilegios y que no quiere desprenderse de ellos, luchando por todos los medios y con todas sus armas para mantener las riendas de esa barca de Pedro que de otra laya se hundiría. Tal vez esta misma obsesión le conduzca no sólo a entretenerse en el Germánico y la Gregoriana en Roma, poniendo en evidencia solamente aquello o a aquellos que le interesan a sus propios "intereses". ¿Todos los demás son unos ignorantes? ¿Buscan solamente el poder y los privilegios? ¿Nadie conoce de exégesis y de crítica histórica? ¿Es él el único o son únicos aquellos a quienes él apela? Cuanto él da a entender sobre sí mismo es dogmático y profesor de teología fundamental y si se ha preparado en exégesis y crítica histórica, es cierto también que no es especialista y que hay otros especialistas que han abordado los mismos temas desde otra perspectiva y otros ángulos diversos. Que se crearon grupos y pequeños "conciliábulos" es una verdad innegable y que esos grupos o "grupúsculos" trataban de influir su propia visión de la Iglesia y su problemática y soluciones, es cierto también. ¿O no ha intentado formar él su grupo centroeuropeo de teólogos en busca de una presión sobre sus cardenales y obispos para imponer, en el ámbito de lo posible, su propia mirada sobre la 
Iglesia? ¿Por qué negar capacidad a los demás, como si hubiera sólo una interpretación de verdades tan complejas, que sería la que él defiende con sus colegas? Y además ¿quién ha dicho a Hans Küng que la Iglesia no estaba preparada, cuando a la hora de la votación de aquellos que él cree algunos de los temas más candentes, siempre o casi siempre ha habido una mayoría aplastante a favor de las tesis que el sentido común de la Iglesia actual -de aquel entonces- admitía ya sin reticencias? ¿Acaso trataron en sus relaciones e intercambios con todos ellos y los convencieron en una charla o en una conversación de minutos? ¿Hablaron acaso con todos? ¿No es considerar en poca cosa a quienes de alguna manera estaban ya convencidos de la necesidad de esas decisiones y no por las palabras, con frecuencia ininteligibles, de esos teólogos de la aparente claridad que se pierden normalmente en oscuras disquisiciones? La claridad es una de sus dotes frente a los enrevesados argumentos y filosofemas de algunos de sus llamados corredores de fondo como él.

Hay en toda esta historia, que quiere ser personal, pero que forzosamente la hace extensible a casi cincuenta años de la historia de la Iglesia, hechos muy sorprendentes. Se admite, por ejemplo -y no puede ser de otra manera-, que no haya más dogmas y que no se proclamen más en el nuevo Concilio, y además que de la doctrina cristiana, no quiere que se hable de católica, hay múltiples y muy variadas opiniones -la diversidad de teologías lo confirman-. Ahora bien, si en un caso y en otro, se pretende que prevalezca una $u$ otra de las interpretaciones, se estaría yendo contra la libertad de pensamiento, de opinión y de expresión dentro de la Iglesia. Y si en cada una de las interpretaciones yace una parte, por diminuta que sea, de la verdad total, no hay por qué no aceptarla y admitirla como una aportación más a esa verdad global a que estamos llamados. ¿Por qué ha de ser su verdad o su interpretación de la verdad la que prevalezca? ¿Solamente porque, en apariencia al menos, engancha mejor con el mundo actual y con los hermanos de las demás confesiones o iglesias? ¿O porque han sido capaces de crear una red mayor de comunicación social y de publicidad y se revelan más en la prensa diaria y en las revistas semanales, mensuales o trimestrales de aquel tiempo?

Y sorprende también que sólo admita la buena intención y la buena voluntad en su trabajo y en su teología y en la de su grupo -centroeuropeo, lo llama él- y no admite lo mismo en los demás. En sus mal llamados opositores existe únicamente, según él, un ansia de poder y de conservar los privilegios en una Iglesia romana que identifica con la Curia, mientras que en los "suyos" existe un auténtico amor a la Iglesia. Aquéllos aman a la Iglesia, 
pero ésta identificada con la curia, y ellos -él y los "suyos", los que seanaman verdaderamente a la Iglesia, a la auténtica comunidad de fieles que viven de la confianza y de la fe en el Cristo, si bien las obras ocupan un lugar secundario. Ya en algún momento y en alguna entrevista al más alto nivel se le reprochaba esta flagrante injusticia.

Es sorprendente además que hable y multiplique su discurso y hasta su misma astucia teológica en o sobre el diálogo con las otras confesiones o iglesias y con sus más notables representantes y que trate de afilar la doctrina eclesial adelgazándola para que ingrese al ojal de las otras primero sin que a las otras confesiones o iglesias se solicite -no se hable de imponerque busquen o den pasos en la dirección de la unidad también, abandonando o restringiendo algunas de sus tesis o teorías. Y es más sorprendente aún que hablando tanto de diálogo, no lo haya comenzado por aquellas personas que, aunque con visiones distintas, pertenecen, al menos oficialmente, a la misma Iglesia. ¿Qué pasa entonces? ¿Son creíbles los pasos que se dan o que se ha pretendido dar hacia la unidad de los cristianos? ¿Quién va a creer en esto, si primero no se entienden -o al menos no tratan de entenderse- los miembros de esta misma Iglesia? Nada especial, es el camino trillado ya en la historia por múltiples personajes que han achacado a la Iglesia, llamada oficial por unos, institucional por otros, curial por los de más allá, no desprenderse de su ropaje exterior y vivir desde el auténtico mensaje evangélico. Así quieren interpretarlo unos y así desean que se analice otros.

$\mathrm{Y}$, sin embargo, sigue en pie la Iglesia bifronte, esa Iglesia que, a través de la historia, ha gemido entre los hombres y ha cubierto su rostro para que allá, en el fondo, no descubran sus especiosos valores y solamente se muestren sus debilidades humanas. Todavía resuena en mi corazón aquella Iglesia espiritual, cuerpo de Cristo, peregrina en la tierra, que requiere una manifestación y una revelación externa y que se multiplica entre santos y pecadores, sin que deje de ser lo que era y siendo ella también pecadora, como institución humana. Se apela a la Iglesia inicial fundada por Jesús de Nazaret y que se ha prolongado en el tiempo y cuya trayectoria no puede olvidarse como si la Tradición careciera de sentido o de valor en la historia. También los Padres de la Iglesia amaban a la Iglesia y glorificaban sus esencias y lloraban sus debilidades en sus miembros. Pero a los Padres de la Iglesia apenas se les menciona, como si fueran ellos los responsables de una ininteligencia entre los cristianos, cuando su lucha inicial a favor de la unidad tiene evidencias insoslayables. Más aún, en alguna ocasión cuando se trata de candidatos a una cátedra en la Universidad de Tubinga, siempre 
promediando los amigos -Herbert Haas, en este caso, que es de la misma opinión- dice:"...y en tercer lugar, el deseado por el antecesor, el ampliamente desconocido Rief, que sólo tiene publicaciones sobre san Agustín y sobre la Escuela de Tubinga" (p. 575).Y hablando de Ratzinger escribe: "Yo sé que él sigue más apegado que yo a la tradición neoescolástica y que concede más importancia a la autoridad de los Padres de la Iglesia (y a Agustín especialmente) y a la que dedicará su clase de presentación" (p. 585). La cátedra de Ratzinger es "de teología dogmática e historia de los dogmas" y la de Hans Küng, de "teología dogmática y ecuménica" (ib.). Su ironía y su descalificación por "tener sólo publicaciones sobre san Agustín y la Escuela de Tubinga" no dice nada a favor de este hombre que en el decanato de la Universidad de Tubinga se enfrenta también a problemas de grupos o grupúsculos -siempre los suyos son los entendidos, sabios e inteligentes y tienen la razón, mientras que los otros carecen de los más mínimos argumentos. En español se dice que "algo tendrá el agua, cuando la bendicen".

Alguien podría recriminarle también a él que los Padres de la Iglesia, la tradición viva de la Iglesia primitiva, no es su fuerte y que suelen brillar por su ausencia en su obra -0 recoge sus testimonios de otros autores, más conocidos en el tema-. Al menos aquí, en sus Memorias no tienen cabida o la tienen muy escasa. Se cita a Cipriano (p. 182), a Cornelio (p. 182), a Gregorio de Nisa (p. 159), a Gregorio Magno (p. 442) y a León Magno (p. 442), y en una ocasión a Orígenes (p. 288), hablando de la interpretación espiritual-simbólica de la Escritura, junto al latino Agustín". Y a Agustín se le cita como Obispo de Hipona (Bona, actualmente) (p. 144) y como referencia entre los "testimonios teológicos importantes" (después de Agustín y Tomás de Aquino...) para esa Iglesia de hombres que es "Iglesia de pecadores" y que para Karl Rahner puede ser hasta "Iglesia pecadora", dice Hans Küng (p. 246).

¿Existe para Hans Küng la tradición en la que se dan varias corrientes, pero una línea conductora, o más bien solamente existe una interpretación histórico-crítica y una exégesis así llamada de la Escritura sacra que, de acuerdo a su pensamiento, le permite y le avala las conclusiones de sus tesis principales? ¿No existe acaso en la vida y desarrollo de cualquier idea o creencia humana o cultura, empleando un término más generoso, una evolución a través de la historia y una transmisión desde su origen que ha enriquecido en cierta medida aquel embrión original? ¿Puede o no puede darse este hecho en cualquiera de los supuestos básicos de la creencia cristiana? ¿Lanzó Jesús de Nazaret su mensaje al mundo para que no se fuera adecuando a las situaciones de cada época y permaneciera en su inmovilismo? 
¿No es más dogmática y conservadora esta posición que aquella que admite la tradición como una vivencia prolongada y enriquecida en el tiempo del mensaje evangélico? ¿Con qué derecho se puede apelar a una experiencia luterana o calvinista o a cualquiera otra cristiana si no se acepta también la vivencia cristiana de la Iglesia primitiva y de los Padres que en circunstancias más difíciles expusieron con su vida y sus escritos el mensaje inicial de Jesús de Nazaret? ¿Que lo impregnaron con frecuencia de las filosofías o del pensamiento reinante en su tiempo? Es cierto, pero lo mismo puede decirse de quienes vivimos el Concilio Vaticano II y de cuantos intervinieron activa o pasivamente en él. Y entre ellos se cuenta, sin duda, el mismo Hans Küng, que también es producto de múltiples influencias, que deja traslucir en estas sus Memorias.

Es su vida y tiene todo el derecho de haberla vivido, de vivirla y de interpretarla como guste, a despecho de que su historia sea siempre la auténtica. Su interpretación es ésta. Hasta 1968 vivió y luchó por la libertad y a partir de ahí: "el acento se desplaza cada vez más de la libertad a la verdad: la verdad que, ésta es mi profunda convicción, sólo puede y debe predicarse, defenderse y vivirse en la veracidad. En los años siguientes se va a ver sometida a prueba mi veracidad, como en los anteriores mi libertad" (p. 596).

José MORÁN

Santibáñez de la Isla 